\title{
כROHOMИЧECRИE HAYRИ
}

\author{
THE IMPACT OF ALTERNATIVE AND RENEWABLE ENERGY ON GLOBAL CLIMATE CHANGE \\ DOI: $10.31618 /$ ESU.2413-9335.2020.5.71.604 \\ Mammadov Joshgun \\ PhD Candidate, \\ Department of Economics and Management, \\ Khazar University, Azerbaijan
}

\begin{abstract}
The article focuses on the negative impact of traditional energy sources and the analysis of its complications on the environment. It has been suggested to use widespread of non-traditional, alternative and renewable energy sources in order to eliminate dependencies on these sources.

The article also examines the role of tax policy in the international area towards increasing alternative and renewable energy production and explores implemented measures. As a result, the importance of employment of Carbon tax which is of particular importance in the development of alternative and renewable energy production has been emphasized.

At the same time, it has been recommended to expand further cooperation with the advanced experience of countries in this area.

Key words: traditional energy sources, alternative and renewable energy sources, ecology, climate change, tax policy, carbon tax.

\section{Introduction}

Rapid growth in the world population and global economic development make it necessary to widely use energy sources. So, if previously people used energy in nature merely for meeting their daily needs, the development of civilization and culture led to the further increase in the demand for energy.

According to statistics, while the use of hard coal was $65 \%$ and biomass was $32 \%$ in the world's fuel energy balance of 1910 , the share of oil in the general balance was totally $3 \%$. And, the natural gas was almost nonexistent. However, after 1930, this condition has changed a bit. Thus, while the share of hard coal fell to $55 \%$ and biomass to $27 \%$, the share of oil rose to $15 \%$ and natural gas to $3 \%$ in the total balance [28].

However, starting from 1970, gradually, oil replaced hard coal and biomass and became main energy source used by people. So, the contribution of oil in the energetic balance for the same period reached up to its historical maximum, about $47 \%$ and thus, the relative share of hard coal decreased $25 \%$ and biomass $12 \%$. The remaining portion of the balance (about 16\%) started to the provided at the expense of natural gas which was widely used gradually and nuclear energy as a new energy source [17, p.1].

However, it is sufficient to take into account the fact that the amount of natural fuel produced only during the period from the beginning of XX to 1980 was higher than the volume of natural fuel produced by humanity during the whole historical era. In particular, natural fuel produced in 1960 - 1980 comprised 40\%

of coal, $75 \%$ of oil and $80 \%$ of natural gas which were produced from the beginning of the century [16, p.3].

However, unfortunately, the use of traditional energy sources to meet the energy demand causes the pollution of environment and also atmosphere. The pollution of atmosphere means discharge of various physical and chemical substances and combinations that may violate gas balance. And it has a significant adverse impact on natural and technogenic environment [2, p.211]. These include harmful substances such as Carbon dioxide $\left(\mathrm{CO}_{2}\right)$, Carbon Oxide (CO), Methane $\left(\mathrm{CH}_{4}\right)$, as well as Sulfur Dioxide $\left(\mathrm{SO}_{2}\right)$ and Nitrogen Dioxide $\left(\mathrm{NO}_{2}\right)$, which cause acid rain in nature, as well as dust, soot etc. Among them, Carbon dioxide $\left(\mathrm{CO}_{2}\right)$ prevails particularly. Thus, according to estimations, every year tens of millions of tons of Carbon dioxide $\left(\mathrm{CO}_{2}\right)$ are thrown into the atmosphere from the burning of energy carriers which are extracted in the form of mineral resources. As a result, there is a "greenhouse effect" in the atmosphere, which leads to possible climate change and global warming, aiming at the destruction of ecology and living environment and paving the way for major disasters [5, p. 301; 3, p. 101].

Global climate change

According to statistics, while in 1965 the total share of Carbon dioxide $\left(\mathrm{CO}_{2}\right)$ emissions into the atmosphere in the world was 11,193.9 million tons, in 1995 this indicator almost doubled to 21,895.7 million tons, and in 2018, increased 3 times and reached $33,890.8$ million tons [19].
\end{abstract}


List of countries by carbon dioxide $\mathrm{CO}_{2}$ emissions - (million tons)

\begin{tabular}{|l|c|c|c|c|c|c|}
\hline \multicolumn{1}{|c|}{ Countries } & $\mathbf{2 0 1 4}$ & $\mathbf{2 0 1 5}$ & $\mathbf{2 0 1 6}$ & $\mathbf{2 0 1 7}$ & $\mathbf{2 0 1 8}$ & $\begin{array}{c}\text { Share } \\
\mathbf{\%}\end{array}$ \\
\hline China & 9223.7 & 9174.6 & 9119.0 & 9229.8 & 9428.7 & 27.8 \\
\hline US & 5300.4 & 5153.7 & 5053.7 & 5014.4 & 5145.2 & 15.2 \\
\hline India & 2083.3 & 2147.8 & 2234.2 & 2316.9 & 2479.1 & 7.3 \\
\hline Russian Federation & 1530.8 & 1489.5 & 1501.5 & 1488.4 & 1550.8 & 4.6 \\
\hline Japan & 1239.6 & 1197.4 & 1178.5 & 1171.8 & 1148.4 & 3.4 \\
\hline Germany & 748.4 & 751.9 & 766.6 & 762.6 & 725.7 & 2.1 \\
\hline South Korea & 644.6 & 656.5 & 662.5 & 678.8 & 697.6 & 2.1 \\
\hline Iran & 588.9 & 585.7 & 593.9 & 622.1 & 656.4 & 1.9 \\
\hline Saudi Arabia & 570.4 & 587.1 & 597.6 & 591.1 & 571.0 & 1.7 \\
\hline Canada & 551.3 & 544.6 & 535.9 & 549.5 & 550.3 & 1.6 \\
\hline Indonesia & 480.6 & 488.6 & 493.1 & 516.1 & 543.0 & 1.6 \\
\hline Other & $9,882.8$ & $10,027.0$ & $10,177.0$ & $10,301.0$ & $10,394.7$ & 30.7 \\
\hline \multicolumn{1}{|c|}{ Total World } & $\mathbf{3 2 , 8 4 4 . 8}$ & $\mathbf{3 2 , 8 0 4 . 4}$ & $\mathbf{3 2 , 9 1 3 . 5}$ & $\mathbf{3 3 , 2 4 2 . 5}$ & $\mathbf{3 3 , 8 9 0 . 8}$ & $\mathbf{1 0 0}$ \\
\hline
\end{tabular}

Notes: Indicators in excess of 500 million tons.

Source: BP, Statistical Review of World Energy-2019 [19]

As can be seen from the table, the major part of Carbon dioxide $\left(\mathrm{CO}_{2}\right)$ thrown into atmosphere accounts for the industrial countries, which makes up about $50 \%$ of the world's population. China ranks first among these countries with an indicator of 9,428.7 million tons $(27.8 \%)$. United States with an indicator of 2,459.1 million tons $(15.2 \%)$ is followed by India with an indicator of 2479,1 million tons $(7.3 \%)$.

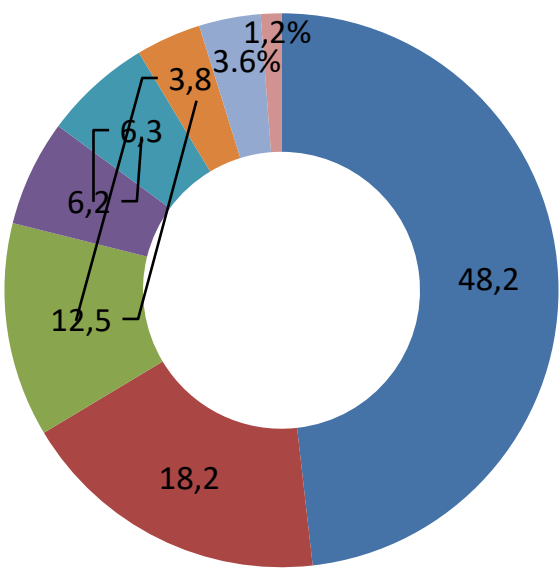

\author{
- Asia \\ north America \\ Europe \\ - CIS \\ Middle East \\ S. \& Cent. America \\ Africa \\ Australia
}

Figure 1 Global Carbon dioxide (CO2) distribution - 2018 (\%)

Hard coal extraction by open - pit method and peat processing cause the change of landscape, even their destruction, as well as, distribution of oil and oil products to large areas during any accident that may occur in oil production and transportation leads to the environmental pollution and thus, the destruction of creatures living in the surrounding area [5, p.301].

The main negative results of oil and gas industry facilities on land resources are as follows [6, p.14]:

-decrease in the productivity of agricultural crops in soils; -conditional degradation of soils due to environmental pollution;

-destruction of wildlife and flora;

-deterioration of public health,

On the other hand, the use of hydrocarbon resources directly or indirectly in the production of plastic products, synthetic fabrics, oils, carbon fiber, and other products as raw materials also contributes to global energy deficits [5, p.304].

Thus, all such adverse events necessitated the intervention of the world countries and the international organizations they represent in this area. Thus, the 
necessity to eliminate such environmental problems that directly threaten human health, at the same time, to use alternative and renewable energy sources was firstly mentioned internationally in 1972 under the United Nations Environment Programme (UNEP). In particular, the appearance of a hole in the ozone layer in 1985 made the fight against climate change even more necessary. So, in September 1987, the Montreal Protocol on Substances that deplete the Ozone layer was signed to reduce their emissions $[9$, p.4; 18, p.8].

Then, the "Framework Convention on Climate Change" (UNFCCC) was adopted at the UN Conference on "Environment and Development" in 1992, in Rio de Janeiro, Brazil. According to the convention, the parties decided to reduce Carbon dioxide $\left(\mathrm{CO}_{2}\right)$ emissions for 10 years in line with the level of 1990 [25].

In December 1997, a Kyoto Protocol was drawn up in Kyoto, Japan, with the participation of the parties at a meeting attended by 2,000 delegates from 159 countries (including Azerbaijan) [21]. The second article of the Protocol encompasses the necessity to encourage use of alternative and renewable energy sources to reduce Carbon dioxide $\left(\mathrm{CO}_{2}\right)$ emissions and to revise the subsidies applicable for conventional energy development [9, p.4]. The "20-20-20" Directive was also compiled under the Kyoto Protocol, according to the requirements of the Directive, commitments to increase energy consumption share by $20 \%$, increase energy efficiency by $20 \%$ and reduce greenhouse gas emissions by $20 \%$ from 1990 levels were determined using alternative and renewable energy sources in EU countries by 2020 [1].

Also, the declaration of the countries taking part in the Copenhagen Climate Summit held in 2009 that $100 \%$ of the total energy demand by 2050 as a target will be met through alternative and renewable energy sources has a much greater impact on the development of this area [9, p. $2 ; 27$, p. 241; 23, pp. 64-65].

Recent agreement is the Paris Agreement signed on December 12, 2015. Agreement came into force on November 4, 2016. According to the agreement, the parties agreed that the increase in the average temperature around the world should be restricted between $1.5^{\circ} \mathrm{C}$ and $2^{\circ} \mathrm{C}[9, \mathrm{p} .4]$.

At the same time, according to the agreement, starting from 2020, the industrialized countries of the world shall allocate $\$ 100$ billion annually to support economically weaker countries that are forced to fight against the negative effects of global climate change. Otherwise, according to the report, the process of people resettlement from permanent residence due to climate change for the period up to 2050 will remain intensive. Thus, it is predicted that up to 200 million people will migrate from their homeland to other places in the status of "Environmental Refugee"[4, p.447].

\section{sources}

Necessity of the use of renewable energy

The United Nations sees the only solution to eliminate society's dependence on traditional energy, at the same time, meet energy demand in the widespread and efficient use of alternative and renewable energy sources. For this purpose, UNESCO has been organizing various events on a regular basis since $90 \mathrm{~s}$ of the last century to expand and develop the use of alternative and renewable energy sources, with the support of UN member states and interested organizations.

There are three main features that distinguish alternative and renewable energy sources from traditional energy sources, here include: [10, p.55]:

1.Alternative and renewable energy sources are renewable and inexhaustible. Traditional energy sources are limited and exhaustible.

2.Alternative and renewable energy sources are environmentally friendly and do not cause pollution of the atmosphere by harmful emissions such as Carbon dioxide $\left(\mathrm{CO}_{2}\right)$. In particular, as the use of alternative and renewable energy sources becomes more widespread, the demand for traditional energy sources will be reduced in future, thus the level of atmosphere pollution will also fall down.

3.Alternative and renewable energy sources are natural and local energy sources.

Thus, this important advantage would reduce each country's dependence on the world's dominant energy producers and ensure the country's energy security. In other words, the risks arising from any changes in the price of fuel products in the world markets will be minimized, thus the country's energy security will be ensured.

Briefly, alternative and renewable energy can also be referred to as a source of energy that exists in nature and is inexhaustible during use $[9$, p.3].

Complications caused by environmental problems

According to the World Health Organization, the number of natural disasters caused by climate change has increased almost threefold since 1960 . So, every year more than 60,000 people die from these disasters, especially in developing countries. In particular, there is an increased risk of bronchial asthma, an inflammatory-allergic disease of the lungs for about 300 million of the world population in the near future due to high temperatures [29].

Only in the summer of 2003, more than 70,000 death facts were recorded in Europe as a result of global warming, according to the organization's report.

According to the organization's forecasts, it is also expected that climate change will lead to the deaths of about 250,000 people during 2030-2050, if this is to continue. It includes 95,000 deaths due to child malnutrition, 60,000 deaths due to malaria, 48,000 deaths due to intestinal disorders (diarrhea), and 38,000 deaths due to heat intolerance of older people.

As for financial expenses, it is forecasted that the direct health costs will be \$2-4 billion by 2030 .

At the same time, melting glaciers, as well as excess heavy rains, cause major floods. As a result, these floods contaminate the freshwater reservoirs, thus creating many disease-bearing insects that increase the risk of spreading dangerous infectious diseases. On the other hand, the floods cause serious damage to the agricultural sector. This has a negative impact on the crop production and leads to food shortages, especially 
in areas where the poor population in the world are living $[4$, p. 443].

At the same time, due to global climate change, some regions of the world experience extreme water shortages and droughts that can lead to massive hunger. Thus, according to the calculations of World Health Organization, over the past 130 years, the temperature in the world has increased by about $0.85^{\circ} \mathrm{C}$. Only in the last 50 years, the atmosphere has been sufficiently polluted with Carbon dioxide $\left(\mathrm{CO}_{2}\right)$ and other greenhouse gases to the extent that it affects the global climate [29].

According to the report entitled "A Region at Risk: The Human Dimensions of Climate Change in Asia and the Pacific", jointly developed by the Asian Development Bank (ADB) and the Potsdam Institute for Climate Impact Research, temperature rise of $6^{\circ} \mathrm{C}$ is expected by the end of the century for the Asian continent. Even some countries in the region may face warmer climatic conditions. Thus, in the northwestern part of Tajikistan, Afghanistan, Pakistan and the People's Republic of China, temperatures are expected to rise up to $8^{\circ} \mathrm{C}$. As a result, unpreventable climatic changes may have destroying and negative impacts on the climate system, agriculture and fishing industry, soil and marine environment, biological resources and other areas of Asian and Pacific countries and hindered their future development [18].

According to the report, while annual rainfall increases up to $50 \%$ across most parts of the region, in countries such as Pakistan and Afghanistan, rainfall is expected to decline by $20-50 \%$. In addition, 13 out of the 20 cities most affected by loss as a result of annual floods in 2005-2050 will account for the Asia-Pacific region.

Increased sensitivity to floods and other diseases will also have serious economic impact on the region and the whole world. Thus, the total amount of damage caused by global floods is expected to increase from $\$$ 6 bln. to $\$ 52$ bln. in the period from 2005 to 2050 .

The report also states that Asian and the Pacific countries, which make up two-thirds of the world's poorest part and one of the world's most vulnerable regions to climate change, are at greater risk of becoming poorer and being exposed to various diseases if they fail to take rapid and serious preventive measures.

At the same time, the World Bank's entitled "End Extreme Poverty - Boost Shared Prosperity" also states that East Asia and the Pacific region are at the heart of global climate changes. So, about one-third of global greenhouse emissions account for the countries of this region. As a result, countries in the region often suffer from the disasters arising from the effects of climate change, such as floods, storms, and the rise in sea level [24, pp. 40-41].

According to the report, $27 \%$ of the World Bank's current loan portfolio for the last three fiscal years has been directed to finance various projects or programs within the framework of combat against climate change. In particular, China owns the largest climate change investment programs covering $70 \%$ of the
Bank's loan portfolio as part of environmental protection.

For example, funds in the amount of $\$ 350 \mathrm{mln}$. allocated by the World Bank within the framework of China Energy Efficiency Finance Program has been a source of stimulus for Chinese banks and as a result, an additional $\$ 2.6$ billion was involved to the sector for the efficient use of alternative and renewable energy sources at the expense of local banks. Thus, as a result of these activities implemented within the program, there has been a decrease in the annual emissions of Carbon dioxide $\left(\mathrm{CO}_{2}\right)$ by 10 million tons. This is equivalent to the amount of Carbon dioxide $\left(\mathrm{CO}_{2}\right)$ emitted from the power station with a capacity of $3 \mathrm{GW}$ in the production of electricity based on the use of hard coal [24, p. 41].

It goes without saying that in a country as huge as China, maintaining environmental balance still remains an urgent issue. So, according to the UN, 16 of the 20 most polluted cities in the world account for China. However, despite this, the Government of China is implementing large-scale programs to ensure environmental security of the country, and specific mechanisms are identified for increasing the material responsibility of enterprises and executive structures for environmental protection. It should also be noted that the banking sector of the country also refuses to provide loans for energy-intensive, environmental pollution projects [7, p.132].

According to the Chinese government, the problem of environmental pollution can only be eliminated by achieving more efficient use of alternative and renewable energy sources.

China's renewable energy policy is based on five basic conditions:

- provision of energy security, prevention of climate change;

- achievement of economic competition, prevention of environmental pollution;

- improving living standards.

To this end, Renewable Energy Law in China was adopted in 2005 and entered into force on January 1, 2006. The law makes it clear that alternative and renewable energy is a priority area for overall energy development in the country $[13$, p. $141 ; 22$, pp. 509; 8 , p.7].

\section{Carbon tax and its use}

Various economic measures (quotas, standards, penalties, etc.) are used to prevent climate change and successfully implement future environmental and economic projects. So, it is through these measures that each state has the opportunity to exercise strict control over the causes of climate change. The most important of these measures is the introduction of carbon tax. Thus, the introduction of carbon tax in the implementation of energy policy is essential and necessary both in terms of preventing air pollution and at the same time increasing the use of alternative and renewable energy sources [11, p.2].

According to the calculations, totally, around 8 billion ton of Carbon dioxide $\left(\mathrm{CO}_{2}\right)$ emissions have been prevented from as a result of using alternative and renewable energy sources in 2007-2017. The main part 
of this, that's, 6.1 billion tons was due to wind power production and 1.8 billion tons due to solar energy production [15, p.245].

Reduction of Carbon dioxide $\left(\mathrm{CO}_{2}\right)$ emissions due to the use of renewable energy sources in 2007-2017 - (million/ton)

\begin{tabular}{|c|c|c|c|}
\hline Year & Solar energy & Wind energy & Total \\
\hline 2007 & 10054,0 & 194204,0 & 204258,0 \\
\hline 2008 & 19748,9 & 249986,0 & 269734,9 \\
\hline 2009 & 28366,5 & 328494,0 & 356860,5 \\
\hline 2010 & 49192,6 & 409068,0 & 458260,6 \\
\hline 2011 & 85698,0 & 491708,0 & 577406,0 \\
\hline 2012 & 121485,4 & 584678,0 & 706163,4 \\
\hline 2013 & 169241,7 & 659054,0 & 828295,7 \\
\hline 2014 & 216998,0 & 764420,0 & 981418,0 \\
\hline 2015 & 278518,6 & 894578,0 & 1173096,6 \\
\hline 2016 & 368405,8 & 1006142,0 & 1374547,8 \\
\hline 2017 & 487018,6 & 1113574,0 & 1600592,6 \\
\hline Total & $\mathbf{1 ~ 8 3 4 7 2 8 , 0}$ & $\mathbf{6 ~ 1 1 1 ~ 2 2 8 , 0}$ & $\mathbf{7 9 4 5 9 5 6 , 0}$ \\
\hline
\end{tabular}

On the other hand, the introduction of carbon tax will also lead to a significant increase in the prices of products or services produced at the expense of traditional energy sources. Thus, a fine in the amount of $\$ 40$ per ton of Carbon dioxide $\left(\mathrm{CO}_{2}\right)$ emissions on average increases by 36 cents the price of one gallon of gasoline, or about by 2 cents per kWh of electricity. This will firstly have a negative impact on transportation costs, as well, industry and agriculture. For this purpose, the introduction of carbon tax can also be regarded as a part of the incentive mechanism in terms of the necessity for wider use of alternative and renewable energy sources [14, p. 374].

Looking at history, we can see that, despite the fact that Carbon tax was debated in the UK about 50 years ago, it was first applied in the world in Finland, Scandinavia in 1990 and then to neighboring Sweden and Norway in 1991. In the following years, the Netherlands and Denmark also started to apply carbon tax. Thus, in these five countries where carbon tax was applied for long term and in a sustainable manner, the average annual income from carbon tax was \$ 202 billion Euros. The highest income belongs to the Netherlands. However, according to the share of carbon tax revenues in GDP, it is $1.88 \%$ in the Netherland on average, but this indicator is $2.1 \%$ in Finland (about $4.5 \%$ in total tax revenues), $2.5 \%$ in Denmark (about
$5 \%$ in total tax revenues) and $2.51 \%$ in Sweden (about $5 \%$ in total tax revenue) [12; 14, p.376].

It should also be noted that this type of tax has also been claimed to have a negative impact on the development of the country's economy in the initial period of the introduction of the carbon tax. However, contrary to the claims, its opposite was observed in the example of Sweden. Thus, despite the fact that Sweden has the highest tax rates in comparison with other countries where carbon tax is applied, the country's economy has grown by more than $100 \%$ since the start of the introduction of carbon tax and has been ranked fourth in the world for competitiveness [14, p.377].

Also, according to calculations, there has been a $1.5 \%$ reduction in the total Carbon dioxide $\left(\mathrm{CO}_{2}\right)$ emissions since the year of introduction of the carbon tax in Norway (in 1991). At the same time, a significant reduction in Carbon dioxide $\left(\mathrm{CO}_{2}\right)$ emissions has been determined in Ireland [12].

It should be taken into account that while the introduction of carbon tax is intended to reduce the level of harmful substances in the atmosphere, on the other hand, it also causes a significant increase in budget revenues. These revenues will be directly or indirectly used by the state to fund socio-economic projects in the future. 
Amount and use of carbon tax by countries in the world

\begin{tabular}{|c|c|c|c|}
\hline № & Countries & $\begin{array}{c}\text { Tax } \\
\text { amount } \\
1 \text { t/dollar }\end{array}$ & Area of use \\
\hline 1 & United Kingdom & 16 & General state budget \\
\hline 2 & Chile & 5 & General state budget, expenditures on education and \\
\hline 3 & Denmark & 31 & $\begin{array}{l}\text { Reduced costs for energy-efficient and environmental } \\
\text { programs, income tax, pension and social insurance }\end{array}$ \\
\hline 4 & Finland & $48-83$ & Reduction of the total state budget, income tax, \\
\hline 5 & France & 24 & $\begin{array}{l}\text { Lower income and corporate taxes, energy assistance } \\
\text { to low-income households }\end{array}$ \\
\hline 6 & Iceland & 10 & General state budget \\
\hline 7 & India & 6 & Clean energy and the environment \\
\hline 8 & Ireland & 28 & $\begin{array}{l}\text { General state budget, budget deficit reduction, debt } \\
\text { repayment }\end{array}$ \\
\hline 9 & Japan & 3 & $\begin{array}{l}\text { Energy Efficiency, Promotion of Clean Energy } \\
\text { Technologies }\end{array}$ \\
\hline 10 & Mexican & $1-4$. & General state budget \\
\hline 11 & Norway & $4-69$. & $\begin{array}{l}\text { General state budget, reduction of income and } \\
\text { corporate taxes, pension plan for low-income people }\end{array}$ \\
\hline 12 & Portugal & 5 & $\begin{array}{l}\text { General government budget, lower income tax for low- } \\
\text { income families }\end{array}$ \\
\hline 13 & South Africa & 8.5 & $\begin{array}{l}\text { Reducing the tax on electricity, energy efficiency, using } \\
\text { a tax discount on solar energy, supporting alternative } \\
\text { and renewable energy, personalized energy services } \\
\text { for low-income people, providing benefits for public } \\
\text { and rail transport }\end{array}$ \\
\hline 14 & Sweden & 132 & $\begin{array}{l}\text { Reduction of the total state budget, income and } \\
\text { corporate taxes }\end{array}$ \\
\hline 15 & Switzerland & 87 & $\begin{array}{l}\text { Tariff reduction for health insurance, ensuring public } \\
\text { safety, energy efficiency, technology development }\end{array}$ \\
\hline
\end{tabular}

Source: World Bank Group - 2017 [26, s.90-128]

As can be seen from the table, in comparison with others, only countries such as India, Japan and South Africa use revenues generated from Carbon tax directly for the protection of the environment and the development of use of alternative and renewable energy sources as clean energy sources to prevent climate changes.

The use of alternative and renewable energy sources in Azerbaijan

Taking into consideration that hydrocarbon resources that significantly determine the political and economic environment of our country, and also have a special weight in meeting our own energy demand are exhaustible, alternative and renewable energy sources are of great importance in maintenance of available resources for future generations, prevention of global climate changes and also, implementation of sustainable energy provision.

Also, the favorable natural and geographical location and climatic conditions of our republic give it more opportunities to use alternative and renewable energy sources. For this reason, the state pays great attention to the development of alternative and renewable energy sources and increasing its special weight in total energy and this area is considered as a priority.

For this purpose, our country has undertaken important political and economic measures to improve and develop national renewable energy policies and has achieved a number of successes. 
Implementation of such measures is, first of all, not only the demonstration of state support for the development of this sector, but also it is of particular importance for stimulating the development of energy production facilities.

\section{Conclusion}

If we take into account the limitations of traditional energy sources and at the same time their negative environmental impacts, the solution of existing problems can only be achieved in two ways:

- decrease in energy consumption with the most efficient and effective use of available traditional energy sources;

- minimize dependence on traditional energy sources, and even eliminate this dependence completely in future.

It is possible by the widespread and effective use of alternative and renewable energy sources as more reliable and clean energy sources in terms of national energy security. It is also important to take into consideration that the energy produced from these energy sources is not high enough at present, which does not allow to completely refuse available energy sources.

For this reason, the introduction of tax policy as an incentive measure which is of particular importance for achieving the development of alternative and renewable energy sources is quite necessary. So, these measures will create conditions for the use of modern equipment and new technologies in alternative and renewable energy production, intensifying investment attraction, and providing the country with high-quality and sustainable energy.

In particular, in the near future, in accordance with the international commitments undertaken by our country, the introduction of carbon tax in our republic and directing the revenues to the development of alternative and renewable energy production can be a positive step. Thus, taking into account that traditional energy sources are exhaustible, the introduction of this tax in our country is very necessary for further expansion of opportunities to use alternative and renewable energy in terms of the environmental protection along with the effective use of available traditional energy sources.

At the same time, cooperation with the countries with progressive achievements and advanced experience in this area should be further expanded.

\section{References}

1.Azerbaijan will become a major producer of alternative energy in the region in the near future, People's Daily reports. October 24, 2013, p. 4 (AZ)

2.Ibragimov I. Environmental Economics. Baku 2015 (AZ)

3.Karimova N.N. Technological pollution of the atmosphere, aquatic system and soil. Bulletin of Baku University, Series of Social and Political Sciences No. 2, pp. 101-114, Baku State University 2009. (AZ)

4.Guliev E. Global food security: realities, problems and prospects. Baku 2018 (AZ)

5.Mamedov A.A., Aliev A.M., Ibragimov E.E., Abasova A.A. Analysis of development trends of the industrial and fuel and energy complex. Baku: 2012 (AZ)

6.Nuralieva R.N. Economic and environmental problems of the development of the fuel and energy complex in Azerbaijan. Baku 2010 (AZ)

7.Samedzade $Z$. China in the global economy. Baku 2009 (AZ)

8.Bayraktar. U., Kaya.KH.I. Comparison of Renewable Energy and Rising Energy Policies: China, Germany and Turkey. Journal of Interethnic Economic Research, 2 (4), pp. 1-18. 2016 (TR)

9.Celikkaya. A. Member of the European Union for the Review of Renewable Energy Investments. Agar T.S. Chairmanship of the Court, Sud magazine, issue 104, October-March 2017, Saturday: 1-26. (TR)

10.Celikkaya. A. Renewable Energy Evaluation Investigation International Interconnection Policy, Eskisehir Osmangazi University, Financial Journal, Ocak-Haziran 2017, No. 172, Sat: 52-84 (TR)

11.Turkey KPMG (Peat Marvik Herdeler Klynveld), as well as tax incentives for renewable energy in 2016 (TR)

12.Ozbilgin.M. Global carbon tax solution and tax efficiency in Turkey. Lebib Yalkin Magazine Content 2017 No. 157 (TR)

13.Ulusoy A.A., Bayraktar. S. Assessment of tax incentives for renewable energy, International Journal of Labor and Society HAK-IS, Volume: 7 Year: 7 Number: 17 Number: 123-160, 1/2018 (TR)

14.Y1ldiz.S. Carbon tax for sustainable development. Journal of accounting and tax applications. No. 10 (3), Ankara 2017 (TR)

15.Gazman V.D. Social and economic efficiency of leasing in renewable energy. HSE Journal of Economics. T. 23. No. 2. P. 238-263. 2019 (RU)

16.Odum G., Odum E. The energy basis of man and nature. Moscow 1978 (RU)

17.17. Fortov V.E., Popel O.S. Renewable energy sources in the world and in Russia. Joint Institute for High Temperatures RAS. Moscow 2013 (RU)

18.Asian Development Bank (ADB) with the Potsdam Institute for Climate Impact Research (PIK). Report: A Region at Risk: The Human Dimensions of Climate Change in Asia and the Pacific. Publication July 2017.

19.British Petroleum Company (BP), Statistical Review of World Energy, June 2019.

20.Ghiollarnath.C.N. Renewable Energy Tax Incentives and WTO Law: Irreconcilably Incompatible? An Examination of the WTOConsistency of Direct Corporate Tax Incentives for the Development of Renewable Energy, Wolf Legal Publishers. 2011

21.Kyoto Protocol to the United Nations Framework Convention on Climate Change. Japan, Kioto 1998.

22.Lo.K. A Critical review of China's rapidly developing renewable energy and energy efficiency policies. Renewable and Sustainable Energy Re-views, №29, 2014.

23.Ruggero S.T. "How Renewables will Change Electricity Markets in the next Five Years", Energy Policy Journal, 48: p.64-75. 2012 
24.The World Bank: "End Extreme Poverty Boost Shared Prosperity". Annual Report 2017

25.United Nations Framework Convention on Climate Change. Brazil, Rio de Janeiro 1992.

26.World Bank Group (march.2017). Carbon tax guide: a handbook for policy makers.
27.Xiaoling.Z, Liyin.S, Sum.Y.C. "The diffusion of solar energy use in HK: What are the barriers?", Energy Policy Journal, 41: p.241-249. 2012

28.www.iea.org - Beynəlxalq Enerji Agentliyinin rəsmi internet ünvanı

29.http://www.who.int/news-room/factsheets/detail/climate-change-and-health - Climate change and health. World Health Organization.

\title{
СОЗДАНИЕ ЭКСПЕРТНОГО СОВЕТА МОЛОДЕЖИ ПО ВОПРОСАМ РАЗВИТИЯ РЕГУЛЯТОРНОЙ ПЕСОЧНИЦЫ ЕАЭС
}

DOI: $10.31618 / \mathrm{ESU} .2413-9335.2020 .5 .71 .607$

Басова Анастасия Геннадьевна

студентка Финансового университета

при Правительстве Российской Федерации

Москва

\section{CREATION AN EXPERTS COUNCIL OF YOUTH ON THE DEVELOPMENTS OF THE EAEU REGULATORY SANDBOX}

\author{
Basova Anastasia Gennadievna \\ Student of Financial University under the Government \\ of the Russian Federation Faculty \\ of International Economic Relations
}

Moscow

\begin{abstract}
АННОТАЦИЯ
С целью развития международного сотрудничества, углубления интеграционных процессов, а также повышения конкурентоспособности страны в условиях цифрового взаимодействия, государства - члены Евразийского экономического союза утвердили основные направления цифровой повестки союза до 2025 года. В рамках данного документа было принято решение о развитие регуляторной песочницы ЕАЭС, которая будет способствовать возникновению новых бизнес-моделей и усиливать трансграничную кооперацию. Статья посвящена рассмотрению вопроса о создании Экспертного совета молодежи по вопросам развития регуляторной песочницы ЕАЭС.
\end{abstract}

\section{ANNOTATION}

In the context of digital interaction for developing international cooperation, deepening integration processes and increasing the country's competitiveness the member states of the Eurasian Economic Union approved the main directions of the digital agenda of the union until 2025. Within the framework of this document it was decided to develop the EAEU regulatory sandbox, which will contribute to the emergence of new business models and strengthen cross-border cooperation. The article is devoted to the question of creating an Expert Council of Youth on the development of the EAEU regulatory sandbox.

Ключевые слова: миграция молодежи, экономическое развитие, финансовые и регуляторные технологии, регуляторные песочницы, экспертный совет молодежи.

Keywords: youth migration, economic development, financial and regulatory technologies, regulatory sandboxes, the Youth Expert Council.

В современном мире уровень развития цифровых технологий влияет на уровень конкурентоспособности страны и ее экономическое развитие. Ключевым фактором экономического роста государств - членов Евразийского экономического союза (далее - ЕАЭС) является переход к цифровой экономике. Такой переход требует изменения существующих подходов к правовому регулированию создания, применения и развития цифровых технологий. В рамках союза ЕАЭС в настоящее время отсутствует перечень единых и согласованных политик в области цифровой трансформации отраслей и рынков. В связи с этим в рамках реализации цифровой

${ }^{1}$ Решение Высшего Евразийского экономического совета от 11 октября 2017 г. № 12 “Об Основных повестки ${ }^{1}$ Распоряжением Евразийского межправительственного совета от 27 ноября 2018 года № 17 «О разработке концепции применения специальных режимов («регулятивных песочниц») были сформированы специальные правовые основания для реализации пилотных проектов в области цифровых технологий.

Создание регуляторной песочницы позволит:

1)Обеспечить качественное цифровое взаимодействие регулирующих органов государств - членов ЕАЭС;

2)Сократить сроки внедрения инновационных продуктов и сроки изменения правового

направлениях реализации цифровой повестки Евразийского экономического союза до 2025 года". 